\title{
Inversion of synrift normal faults in the High Atlas Mountains, Morocco
}

\author{
WeLDON BEAUCHAMP and MuAWIa BaRAZANGI, Cornell University, Ithaca, New York \\ AHMED DEMNATI and MOHAMED EL ALJI, Office National de Recherches et d'Exploitations Petrolieres, \\ Rabat, Morocco
}

Structural inversion related to intracontinental rifting occurs when extensional rift faults reverse their sense of motion during subsequent episodes of compressional tectonics. Features generated by extension, such as half grabens, are uplifted to form positive anticlinal structures.

Mountain belts resulting from the convergence of continent-continent or continent-oceanic plates usually form along the margins of such plates. In contrast, intracontinental mountain belts such as the Atlas Mountains of North Africa, the Palmyrides of Syria and the Cordillera Oriental/Merida of Colombia and Venezuela often form hundreds of kilometers from nearby plate boundaries. Stresses generated by plate convergence are transmitted to the interior of continental plates where the strain is accommodated along preexisting zones of weakness in the crust, such as rifts, aulacogens, and sutures, resulting in intracontinental mountain belts. The High Atlas Mountains of Morocco are an intracontintental mountain belt formed by the inversion of a preexisting Mesozoic rift system (Figure 1). The Atlas Mountains of North Africa extend for approximately $2000 \mathrm{~km}$ from the Atlantic margin of Morocco to the Mediterranean coast of Tunisia, and were formed during the Alpine orogeny in the MioceneOligocene.

Exploration objectives. Many large rift systems such as the Atlas contain attractive components for hydrocarbon exploration: rich organic source rocks, thick evaporite/volcanic rocks providing seals, and clastic submarine fans and/or carbonate buildups forming reservoir rocks. Rift basins contain only about $5 \%$ of the world's sedimentary rocks, but these rifts contain $10-30 \%$ of proven hydrocarbons.

Intracontinental mountain belts formed by inversion provide complex, yet prospective exploration targets with similar potential to rift

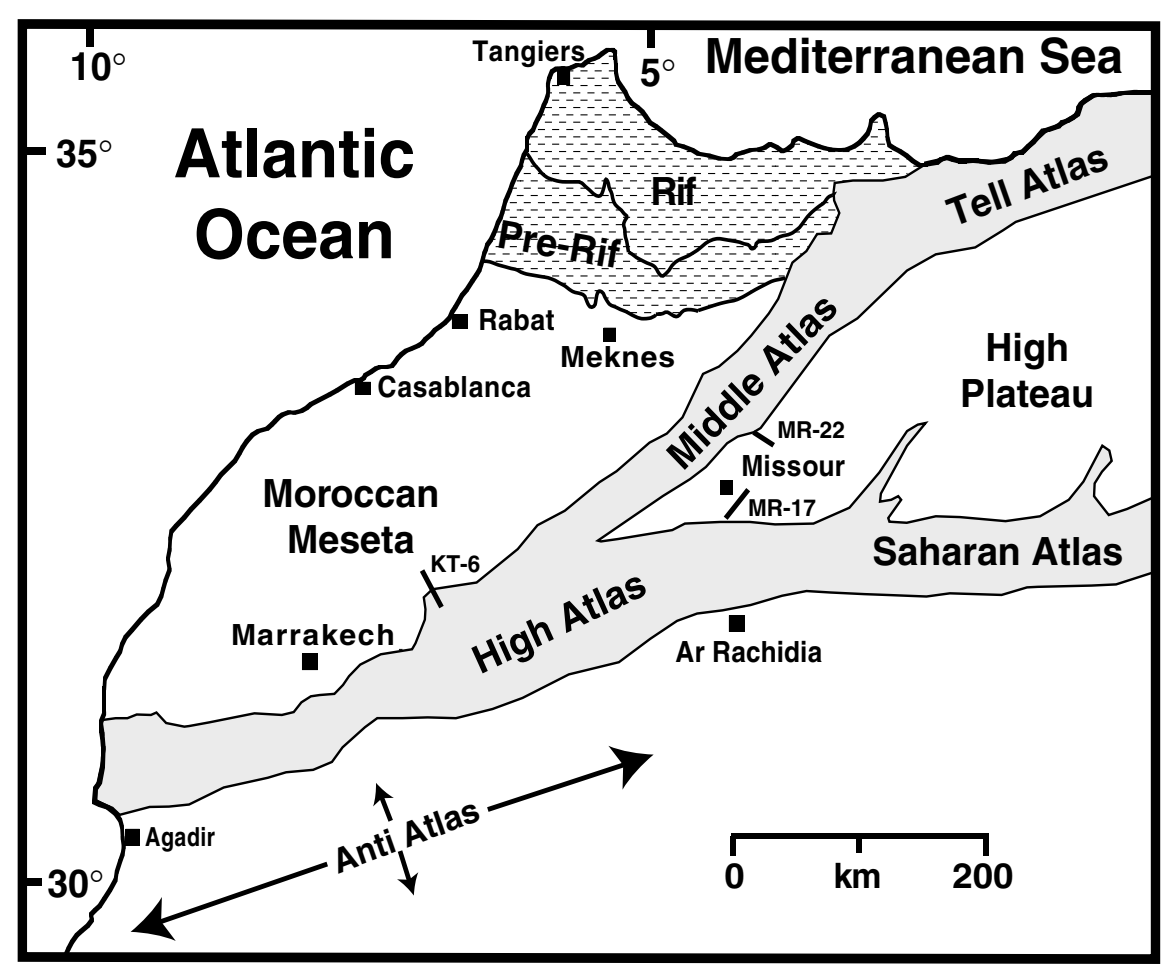

Figure 1. The tectonic units of northern Morocco and location of seismic lines used in this study.

basins. Consequently, it is important to understand the geometry and kinematic history of structures formed during inversion to reduce exploration risk, to acquire seismic reflection data, and to identify prospects. Depending on the amount of inversion and shortening, traditional hydrocarbon traps like those in productive rift basins (e.g., the North Sea and the Euphrates graben in Syria) may still have maintained their integrity. The orientation of a rift basin relative to the regional stress field may determine whether the basin is affected by inversion tectonics. For example, the Palmyrides of Syria were oriented normal to plate convergence during the Cenozoic, resulting in uplift and inversion of the Palmyride trough. The Euphrates graben in eastern Syria was oblique to the direction of convergence, and hence, was subjected to minimal inversion.
The Atlas rift system of Morocco was inverted and uplifted due to convergence between the African and European plates during the Cenozoic. This mountain belt represents a huge region, about $2000 \mathrm{~km}$ long and $100 \mathrm{~km}$ wide, which is virtually unexplored.

Hydrocarbon traps generated in the syn-rift and post-rift phases may be destroyed during inversion resulting in the remigration of hydrocarbons. The same inversion and uplift may also generate favorable traps in the footwalls of new thrust faults. These new footwall traps focus remigrated hydrocarbons and collect hydrocarbons generated in new foreland basins along the mountain belt. For example, the northern region of the Llanos Basin of Colombia, an area with significant recent discoveries (Cordillera Oriental), represents the margin of an inverted rift approximately the same age as the 
Atlas and the North Sea rifts (Triassic-Jurassic).

Recognizing inversion. It is important to identify if a fault was originally a normal fault, and if so, whether or not it has been reactivated. Common criteria such as sedimentary thickening into a fault (e.g., growth fault), and hanging wall rollover will identify the sense of displacement of a normal fault. Syn-rift sedimentary rocks such as those in the Atlas have an inherited extensional history of deformation. A structure formed by extensional deformation will have a different geometry upon inversion than a compressional structure generated in undeformed rocks. For example, structures resulting from inversion are different than those produced by fault-bend and fault-propagation style folds, due to the preexisting fault shapes and previously deformed sedimentary rocks in the hanging walls of normal faults. Furthermore, the evolution of a rift basin to an intracontintental mountain belt may involve a combination of thin-skinned and thick-skinned deformation.

Identification of inversion is not always straightforward, as can be shown on seismic line MR17 from the northern margin of the High Atlas in the Missour Basin (Figures 1 and 2). Reactivation of a syn-rift fault may have resulted in a newly formed high angle reverse fault in the postrift sedimentary rocks. Only a slight thickening of syn-rift strata into the fault from north to south and truncation of Jurassic rocks by the base Cretaceous unconformity indicate this fault may be a inverted fault. Erosion of syn-rift Jurassic rocks, indicated by the base Cretaceous unconformity, has removed most of the evidence that this may have been an active fault during rifting.

Inversion in the Atlas Mountains. Many of the interpretations and models created as a result of this study could not have been achieved without detailed geological field mapping along the routes of previously acquired seismic reflection profiles. The Atlas Mountains contain a variety of structural styles that resulted from reactivation of preexisting faults as well as the generation of new faults. Thin-skinned structural styles are characterized by bedding which is parallel to hanging wall ramps and flats of thrust faults. Deformation in the Atlas has also occurred by thick-skinned deforma-

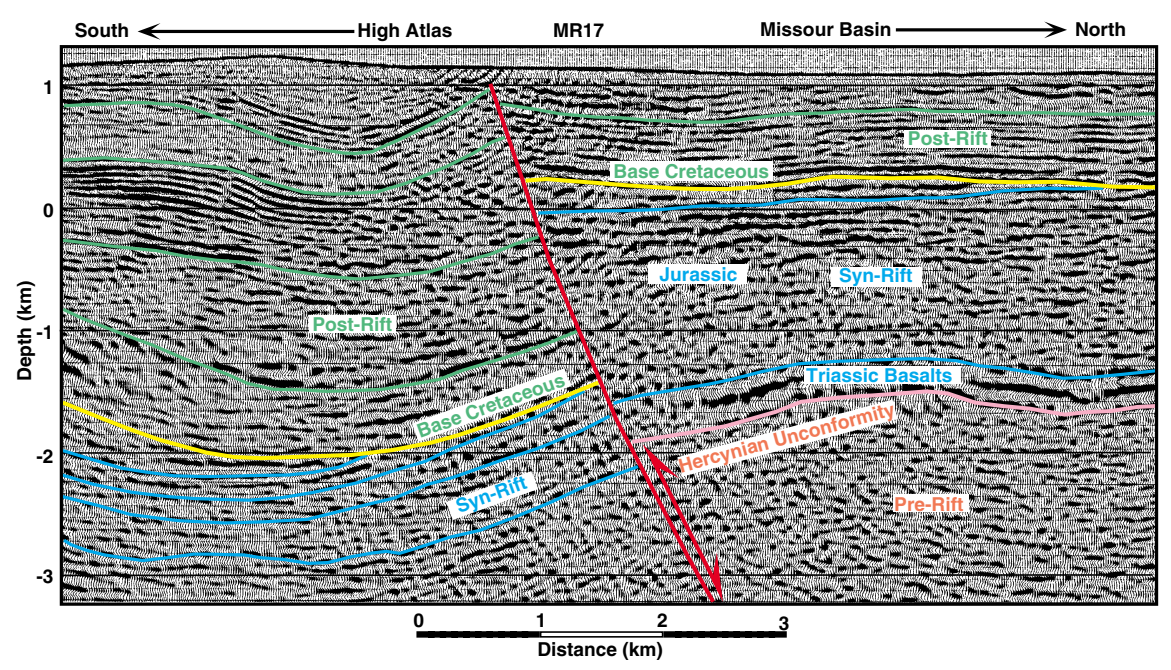

Figure 2. Seismic line MR-17 from the northern margin of the High Atlas Mountains and southern Missour Basin; no vertical exaggeration (Figure 1). MR-17 clearly shows faulting with a reverse sense of slip, but it is difficult to determine if the fault is reactivated and whether inversion has occurred. Reactivation of a syn-rift fault at depth may have resulted in a new high angle reverse fault in the post-rift strata. (Modified from Beauchamp et al., 1996, reprinted by permission of the AAPG).

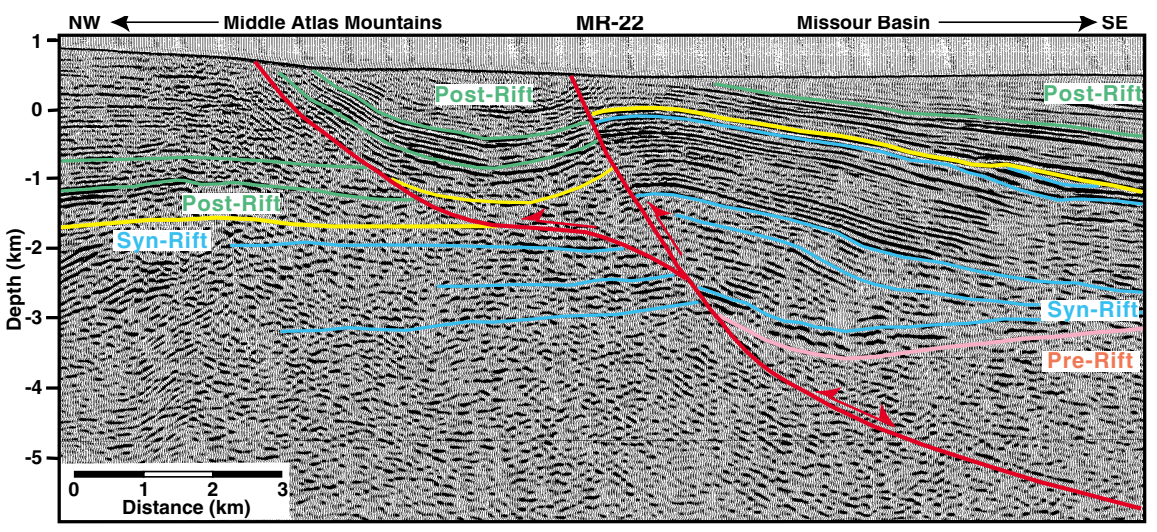

Figure 3. Migrated and depth-converted seismic line MR-22 from the southeastern margin of the Middle Atlas Mountains (Figure 1), illustrating the geometry of a reactivated syn-rift fault and resulting footwall short cut fault. Reflections in syn-rift age rocks show thickening into a listric normal fault. No vertical exaggeration. (Modified from Beauchamp et al.)

tion with the reactivation of preexisting syn-rift faults and previously deformed syn-rift rocks. Structural geometries resulting from the inversion of syn-rift faults were recognized on seismic reflection data and from geological maps. These relationships include nonparallel bedding (previously deformed) and stratigraphic thickening of syn-rift rocks in the hanging wall of thrust faults.

A seismic line from the margin of the Missour basin and the Middle Atlas Mountains illustrates a clear example of inversion tectonics and fault reactivation (Figure 3). Seismic line MR-22 was migrated, converted to depth, and displayed with no ver- tical exaggeration to determine the kinematic history (Figures 3 and 4). Thickening toward a listric normal fault shown by reflections in syn-rift Triassic and Jurassic sedimentary rocks can clearly be seen on line MR22. The base of the syn-rift sedimentary sequence is marked by strong reflections in the Triassic generated by interbedded volcanic, evaporite, and clastic rocks. A palinspastic restoration of line MR-22 was achieved by placing a pin line in the footwall and a loose line in the hanging wall of the reactivated fault (Figure 4). An interpretation of this line suggests inversion of the syn-rift normal fault occurred along the original fault plane until the fault began to 
steepen, at which time it became mechanically more efficient to generate a new thrust fault in the footwall (footwall short-cut fault) allowing continued shortening and inversion. The new thrust fault in the footwall moved along a flat until ramping upwards to the surface. Displacement along this fault system continued with the syn-rift sedimentary rocks that were deposited in a half graben, eventually thrust over the new ramp forming a fault-bend fold (Figure $4 b$ ). Finally, a new high-angle breakthrough formed along the forelimb of the new ramp anticline and accommodated further shortening (Figure 4c). Shortening across this structure is not large $(\sim 3 \mathrm{~km}$, about $15 \%)$, but the structure clearly illustrates the kinematic history of inversion.

Faulting along the margin of the High Atlas Mountains, west of the Missour Basin shows what can happen when a rift basin is oriented orthogonal to the direction of compression that results from plate convergence (Figure 5). A portion of seismic line KT-6 acquired by ONAREP (Office National de Recherches et d'Exploitations Petrolieres) along the margins of the High Atlas northeast of Marrakech (Figure 1), shows the structural syncline of Ait Attab. The Ait Attab syncline is over $10 \mathrm{~km}$ wide and contains syn-rift Lower-Middle Jurassic rocks, with Upper Cretaceous rocks preserved along the axis of the fold. These strata clearly thicken from southeast to northwest and are interpreted to have originally been deposited in an extensional half graben (Figure 5). The lower part of the seismic section (pink) shows reflections in syn-rift rocks that are not folded and dip to the southeast. These reflections are below the major thrust formed in the footwall of a syn-rift normal fault. This fault is exposed along seismic line KT-6 to the northwest where it thrusts Lower Jurassic rocks over Upper Cretaceous rocks. Jurassic and Cretaceous rocks in the hanging wall of this thrust were probably transported up a reactivated normal fault related to a half graben to the southeast, and then along a newly formed thrust fault (Figure 5) towards the margins of the rift basin. Shortening along this portion of line KT- 6 is over $10 \mathrm{~km}$.

Models of tectonic inversion. Numerous case studies from around the world show where tectonic inversion has occurred (see "Suggestions for further reading"). Physical

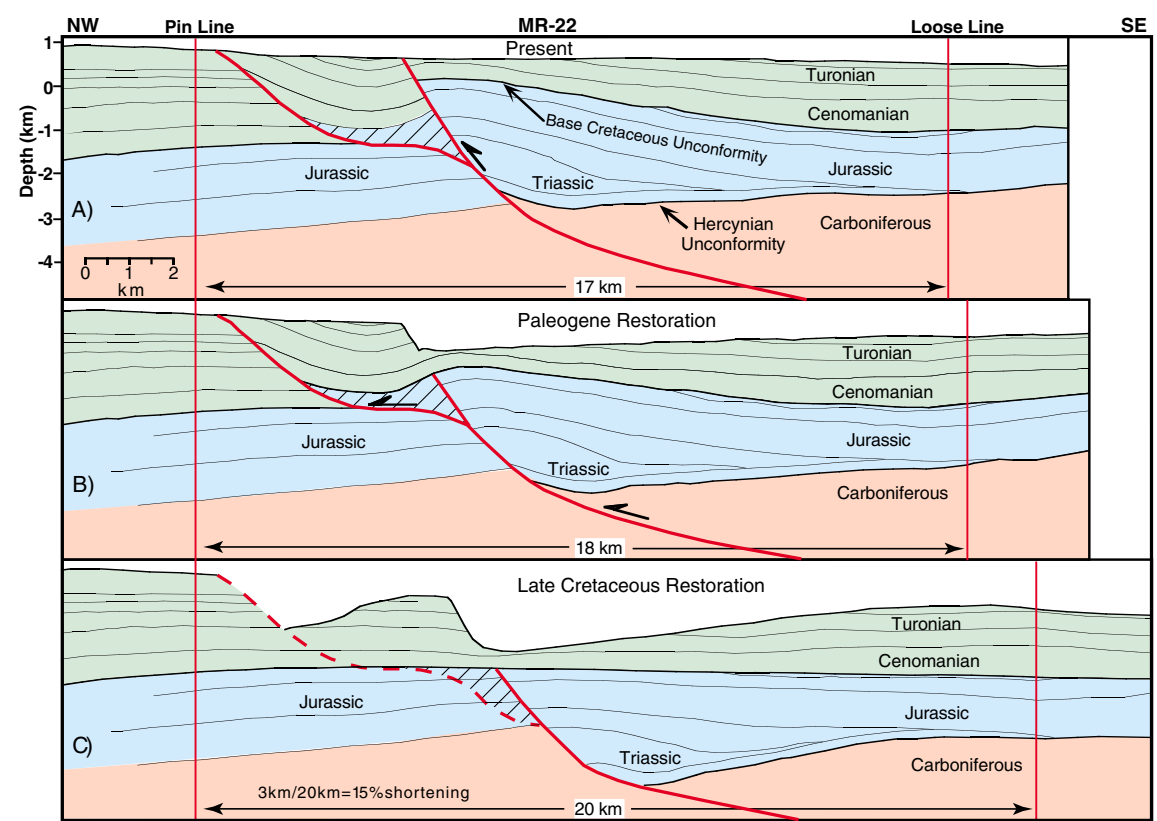

Figure 4. A palinspastic restoration of line MR-22 (c) with the reactivation of a syn-rift listric fault during the Paleogene (b), and the formation of a footwall short-cut fault. Slip along these two faults formed a fault-bend fold over the resulting ramp, until a high-angle fault broke through the forelimb (a). (Modified from Beauchamp et al.)

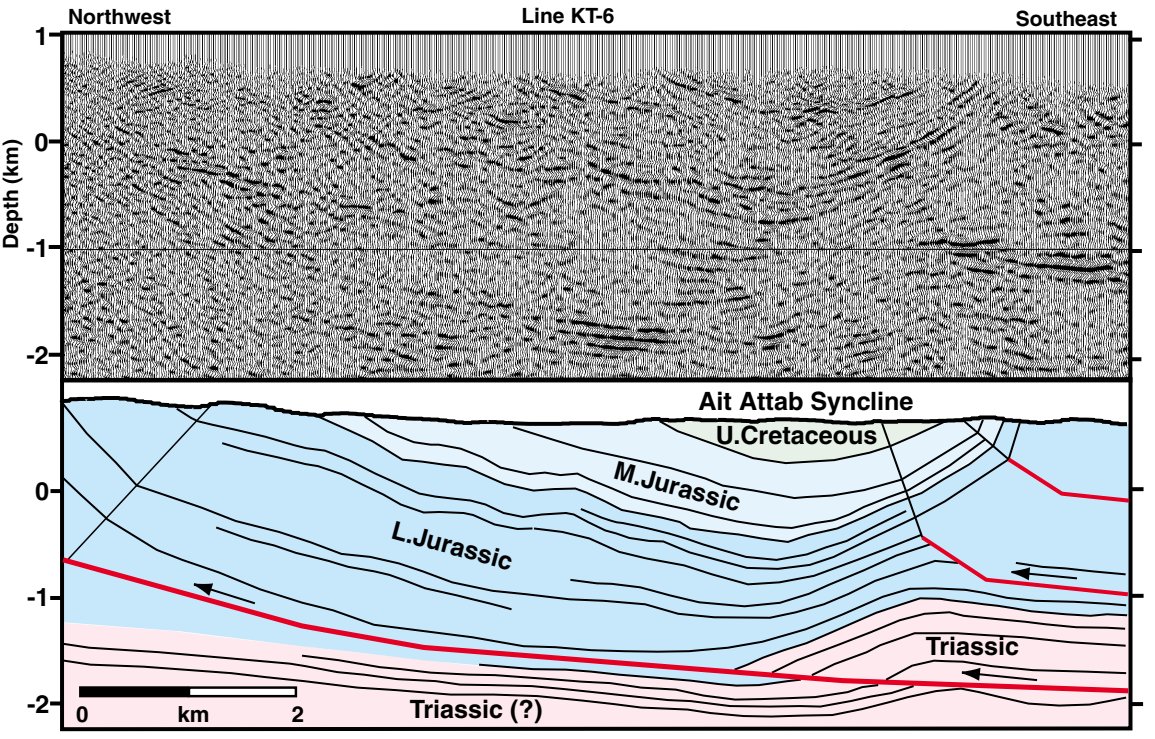

Figure 5. Part of seismic line KT-6 across the Ait Attab syncline in the northern High Atlas northeast of Marrakech (Figure 1). Reflections from folded syn-rift Jurassic rocks and post-rift Cretaceous rocks show thickening from southeast to northwest across the syncline. These folded rocks in the syncline lie above a major thrust fault (exposed to the northwest) that formed in the footwall of a syn-rift half graben. These folded rocks in the Ait Attab syncline were transported up a reactivated normal fault and along the hanging wall of a newly formed thrust.

and kinematic models are based upon various assumptions and constraints (e.g. choice of rheologies, fixed footwalls, layer parallel shear, vertical simple shear, inclined simple shear, planar faults and listric faults) and predict structures that are unique to each type of model. Inversion styles worldwide contain similarities to modeled inversion geometries but, in general, each case is unique. The inherent complexity and variability of inverted basins should be studied individually using a vari- 
ety of appropriate techniques. Based on geological and geophysical observations, models were created to help explain the kinematic and deformational history of the Atlas Mountains (Figures 6 and 7).

Structural relationships commonly found in rift basins (such as lowand high-relief accommodation zones, pull-apart basins, extensional transfer zones, and changes in fault polarity) will often affect the type of structures generated during inversion. Field relationships mapped in the Missour Basin and Atlas Mountains present life-size models which were studied to better understand the affect of syn-rift structures upon structures formed during inversion (Figure 6). Opposing half grabens separated by an accommodation zone formed during the syn-rift phase can later result in complex structural relationships upon inversion (Figure 6). Two opposing half grabens bounded by normal faults result in fault-bend or fault-propagation folds when compression is normal to the graben trend. The resulting folds have opposite (sense of) vergence resulting in the transport of thicker syn-rift strata from the hanging wall of the thrust over thinner syn-rift strata from the footwall. These two inversion-related folds are separated by complex oblique-slip zones (flower structures).

A computer program was used to model the kinematics of a simple listric normal fault with syn-depositional thickening and its subsequent structural inversion styles. The model assumes displacement of rocks in the hanging wall is laterally uniform, and that the footwall is fixed and rigid. The deformation mechanism is vertical simple shear for the reactivated normal fault, and layer-parallel shear for the newly formed fault-bend fold (Figure 7). A pin line and loose line were placed in the model to show relative displacement and shortening. The model assumes that upon reactivation a thrust fault forms in the footwall of the normal fault between the postrift and pre-rift strata. Deformation by this model creates a hanging wall anticline over what is effectively a footwall ramp, resulting in a faultbend-fold structure. The model shows that above the new thrust fault syn-rift bedding is not parallel to the footwall flat, which is the same relationship found along thrust faults interpreted on seismic reflec- tion data in the Atlas Mountains (Figures 3 and 5).

The effect of the inversion of an intracontinental rift may be that deformation occurs by layer-parallel shear in post-rift sedimentary rocks, which are unfaulted, undeformed and contain only moderate changes in bedding thickness. Vertical or inclined simple shear approximates the deformation of syn-rift rocks characterized by preexisting faults, previously deformed rocks, and drastic changes in sedimentary thickness. It is likely that the reactivation of synrift faults as thrusts and the formation of new thrusts within post-rift rocks occur simultaneously.

Conclusions. Intracontinental mountain belts such as the Atlas Mountains of Morocco contain the necessary elements for successful exploration ventures. Thrusting along the margins of inverted rift basins creates foreland basins where new hydrocarbons are generated. These margins are regions where oil and gas generated during the syn-rift and post-rift phases may remigrate as a result of inversion tectonics. Hydrocarbons trapped in the footwall of new thrusts may be sealed by evap-

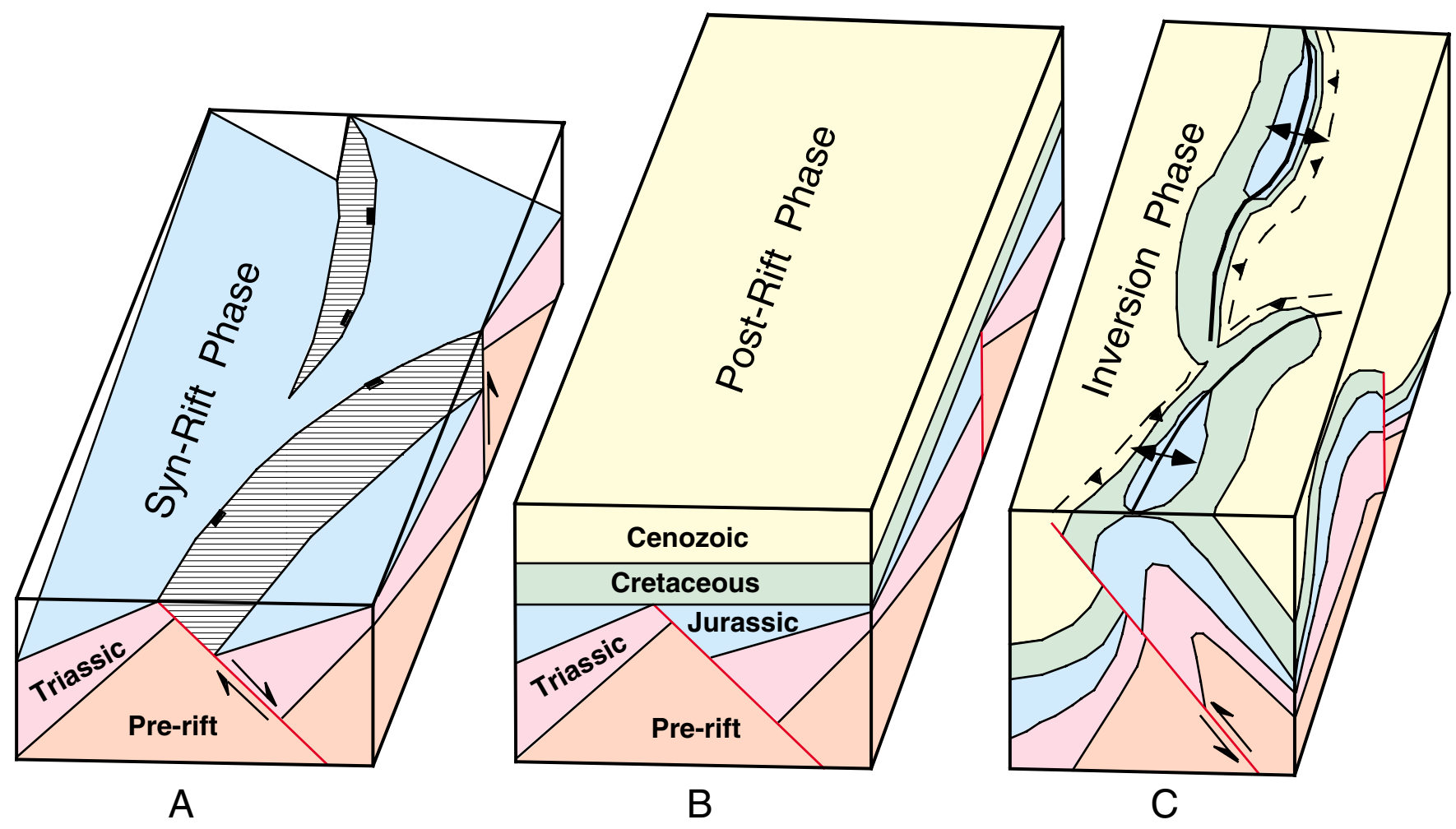

Figure 6. Block diagrams based upon structural relationships mapped in the field depicting the effects of pre-existing syn-rift structures upon inversion structures. Two opposing syn-rift half grabens are inverted along existing reactivated faults resulting in two oppositely verging fault-propagation folds. 


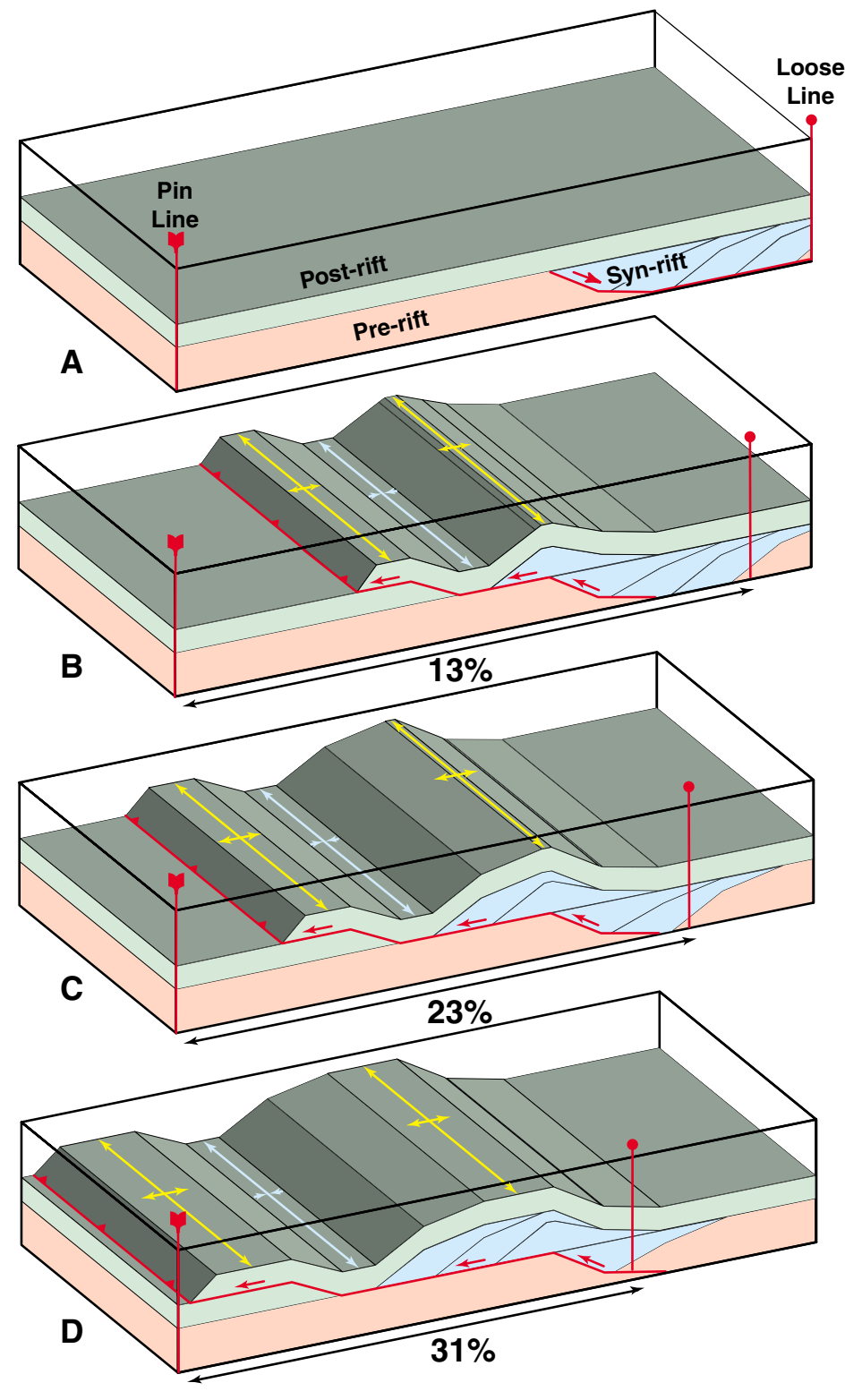

Figure 7. (a) Kinematic model of the inversion of a syn-rift half graben. (b) Compression normal to the half graben reactivates the syn-rift fault, moving syn-rift rocks up the hanging wall until a new thrust fault forms between the post-rift and pre-rift rocks. (c) Syn-rift strata are transported over the newly formed ramp, creating a fault-bend fold. Syn-rift rocks are not parallel to the hanging wall flat of the thrust because they were previously deposited and deformed in the hanging wall rollover of the listric normal fault. A new ramp forms in the direction of transport creating a new fault-bend fold. (d) Compression normal to the original half graben results in shortening of $31 \%$.

orites in the hanging wall providing new subthrust traps. The increased resolution of complex structural terranes provided by 3-D seismic methods creates new exploration opportunities and reduces exploration risk.

Suggestions for further reading. "Intracontinental rifting and inversion: the Missour Basin and Atlas Mountains of Morocco" by Beauchamp et al. (AAPG Bulletin, matic evolution of inversion structures by S. Mitra (AAPG Bulletin 1993). E

Acknowledgments: This study would not have been possible without the assistance of ONAREP (Office National de Recherches et d'Exploitatiors Petrolieres) and the Geological Survey of Morocco. Many thanks to our colleagues at Cornell who reviewed this manuscript. Acknowledgment is also made to the donors of the Petroleum Research Fund, administered by the American Chemical Society (ACS-PRG \#29505-AC2) and to a grant from ASERT (\#DAAH04-94G-0361) for support of this research.

Corresponding author: W. Beauchamp, phone 607-255-5514, fax 607-254-4780, email weldon@geology.cornell.edu 